\title{
Carcinoma of the Eyelid pTis TNM Finding v7
}

National Cancer Institute

\section{Source}

National Cancer Institute. Carcinoma of the Eyelid pT is TNM Finding v7. NCI Thesaurus.

Code C88562.

Carcinoma of the eyelid with a finding of carcinoma in situ. (from AJCC 7th Ed.) 